\title{
Replikasi SIPBM, Pembentukan POSPAUD, dan Peningkatan Mutu Dokter Kecil di Desa Cigadung dan Parereja Kecamatan Banjarharjo Kabupaten Brebes
}

\author{
Isti Hidayah ${ }^{1}$, Lita Latiana $^{2}$, Widowati $^{3}$, Tatirah $^{4}$ \\ ${ }^{1,2,3}$ Universitas Negeri Semarang \\ ${ }^{4}$ AKBID YPBHK Brebes \\ isti.hidayah@mail.unnes.ac.id
}

\begin{abstract}
Key word:
Replication

SIPBM

(Community

Based

Development

Information

System),

POSPAUD,

little doctor

\section{Kata Kunci}

Replikasi

SIPBM,

POSPAUD

dokter kecil

\section{Abstract}

The target of the Partnership Program's activities is Parereja and Cigadung village, district of Banjarharjo, Brebes regency. Priority issues that be the focus on this partnership program are: (1) Quite a lot of early childhood have not served yet in PAUD; (2) There are school-aged children in primary education level not going to school; (3) The high number of stunting and maternal mortality rate (4) The lack of awareness about nutrition of pregnant women and toddlers; (5) The lack of health services for children in school. The target that has been achieved are: (1) The availability of community-based education data in 2018 as a reference for organizing Cigadung village program in the next year; (2) Formed a POSPAUD model in Parereja; (3) formed PKBM in Parereja; (4) The availability of the health equipment and skills of the UKS and little doctor in Cigadung 01 and Parereja 01 elementary school. The methods that used in this program are the empowerment of the Community (communitybased), training approaches, demonstrations, simulations, and practice with assistance. In addition, followed by strengthening community-based human resources who collaborate-participatively with Baperlitbangda and local college to ensure the quality and sustainability of the program.

\section{Abstrak}

Sasaran kegiatan Program Kemitraan adalah Desa Parereja dan Cigadung, Kecamatan Banjarharjo, Kabupaten Brebes. Isu-isu prioritas yang menjadi fokus pada program kemitraan ini adalah: (1) Cukup banyak anak usia dini belum dilayani PAUD; (2) Ada anak usia sekolah di tingkat pendidikan dasar yang tidak bersekolah; (3) Tingginya angka stunting dan angka kematian ibu (4) Kurangnya kesadaran tentang gizi ibu hamil dan balita; (5) Kurangnya layanan kesehatan untuk anak-anak di sekolah. Sasaran yang telah dicapai adalah: (1) Tersedianya data pendidikan berbasis masyarakat pada tahun 2018 sebagai referensi untuk menyelenggarakan program desa Cigadung pada tahun berikutnya; (2) Membentuk model POSPAUD di Parereja; (3) membentuk PKBM di Parereja; (4) Ketersediaan peralatan kesehatan dan keterampilan UKS dan dokter kecil di SD Cigadung 01 dan Parereja 01. Metode yang digunakan dalam program ini adalah pemberdayaan Komunitas (berbasis masyarakat), pendekatan
\end{abstract}


pelatihan, demonstrasi, simulasi, dan praktik dengan bantuan. Selain itu, diikuti oleh penguatan sumber daya manusia berbasis masyarakat yang berkolaborasi-partisipatif dengan Baperlitbangda dan perguruan tinggi setempat untuk memastikan kualitas dan keberlanjutan program

\section{PENDAHULUAN}

Angka Harapan Hidup Kabupaten Brebes menempati peringkat 33 dari 35 Kabupaten di Jawa Tengah. Hal ini menunjukkan bahwa masih banyak permasalahan dan tantangan di bidang kesehatan yang harus diselesaikan bersama, mulai dari perilaku hidup bersih dan sehat, sanitasi lingkungan, kelayakhunian tempat tinggal, fasilitas pelayanan kesehatan, kualitas dan kapasitas pelayanan kesehatan, ketersediaan tenaga kesehatan, kecukupan gizi, tingkat kejadian penyakit, layanan pendampingan kesehatan ibu dan anak, serta tidak kalah pentingnya adalah peran serta masyarakat dalam membudayakan perilaku hidup bersih dan sehat. (RPJMD Kabupaten Brebes, 2017). Sedangkan peringkat Indeks Pembangunan Manusia (IPM) Kabupaten Brebes juga menempati peringkat terendah di Jawa $\begin{array}{lll}\text { Tengah dengan } & \text { skor } & 63.98\end{array}$ (Baperlitbangda, 2016). Kabupaten Brebes terdiri atas 17 kecamatan, salah satunya adalah kecamatan Banjarharjo. Kecamatan Banjarharjo meliputi 25 desa, dua diantaranya adalah desa Parereja dan desa Cigadung. Kecamatan Banjarharjo berada dalam tingkat kesejahteraan yang rendah. Memperhatikan data yang ada, kondisi desa Parereja dan Cigadung relatif sama. Selain petani/ternak sebagai mata pencaharian penduduk desa Parereja dan Cigadung, mata pencaharian penduduk desa Parireja didominasi buruh tani dan pedagang, sedangkan penduduk desa Cigadung didominasi oleh buruh bangunan. Kondisi pendidikan di desa sasaran disajikan seperti pada Tabel 1.

Tabel 1. Tingkat Pendidikan Penduduk Parereja dan Cigadung

\begin{tabular}{lccccc}
\hline \multirow{2}{*}{ Desa } & $\begin{array}{c}\text { Tdk/Blm Tamat SD } \\
\text { Tidak Punya Ijasah SD }\end{array}$ & $\begin{array}{c}\text { Tamat } \\
\text { SD }\end{array}$ & $\begin{array}{c}\text { Tamat } \\
\text { SMP }\end{array}$ & $\begin{array}{c}\text { Tamat } \\
\text { SMA }\end{array}$ & $\begin{array}{c}\text { Tamat } \\
\text { Dipl/Universitas }\end{array}$ \\
\hline Parireja & 3.474 & 1000 & 444 & 318 & 28 \\
\hline Cigadung & 1.710 & 2.381 & 1.515 & 173 & 34 \\
\hline \multicolumn{2}{c}{ Sumber: Data Demografi Desa Parereja dan Cigadung (2017) }
\end{tabular}

Kondisi di bidang kesehatan dari kedua desa relatif sama, namun desa Parereja telah mengalami perkembangan yang cepat, salah satunya untuk progam jambanisasi di desa Parireja hampir 100\% setiap KK telah memiliki jamban, sedangkandi desa Cigadung belum dimulai. Walaupun demikian, kesadaran untuk 
buang air besar (BAB) di sembarang tempat masih ada. Pernikahan dini masih ada. Pelayanan kesehatan melalui POSYANDU dengan jumlah kader 23 orang. tersedia dengan rincian pada Tabel 7 berikut.

Tabel 2. POSYANDU di Desa Parereja

\begin{tabular}{llc}
\hline No. & Nama POSYANDU & Jumlah Terlayani \\
\hline 1 & POSYANDU Asoka 1 & 136 \\
2 & POSYANDU Asoka 2 & 71 \\
3 & POSYANDU Asoka 3 & 86 \\
4 & POSYANDU Asoka 4 & 145 \\
\hline \multicolumn{2}{c}{ Total } & 438 \\
\hline
\end{tabular}

Kegiatan pendataan terakhir yang dilakukan adalah pada tahun 2017 yaitu pendataan berbasis masyarakat yang dilakukan Baperlitbangda (Badan Perencanaan Pembangunan, penelitian, dan pengembangan Daerah) Kabupaten Brebes dengan Unicef, dan Universitas Negeri Semarang dengan SIPBM (Sistem Informasi Pembangunan Berbasis Masyarakat) terkait pendidikan, kesehatan, demografi, air dan sanitasi, sosial dan ekonomi, perumahan, dan perlindungan anak. Masih terdapat anak usia dini yang cukup besar (197 anak) belum terlayani PAUD). Data ini dapat dilihat pada Gambar 1. Di desa Parireja hanya tedapat 2 PAUD dan 1 RA yang baru berdiri. Terdapat 226 anak usia sekolah (7-18 tahun) yang tidak sekolah, data ini disajikan pada Gambar 2.

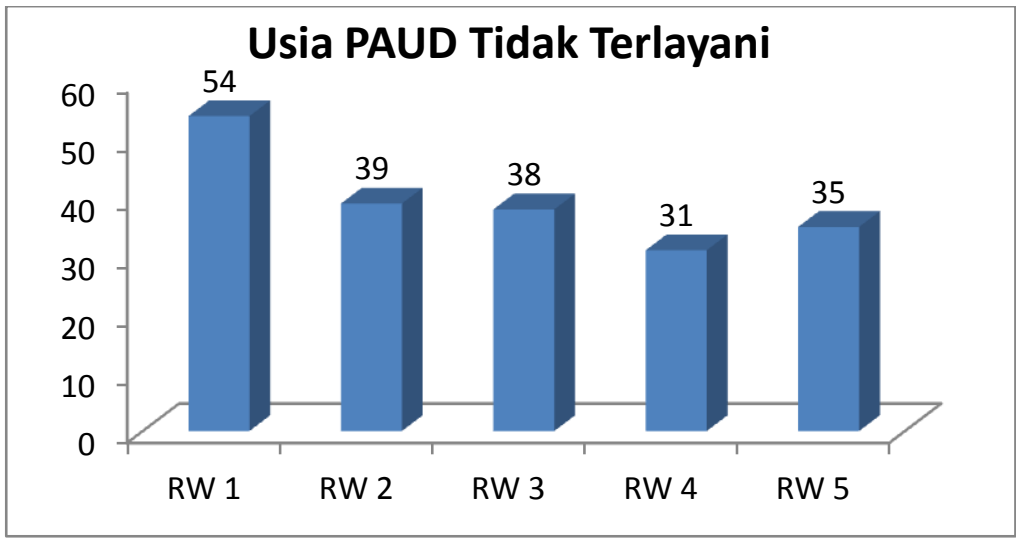

Gb. 1. Diagram Usia PAUD Tidak Terlayani di Desa Parereja 


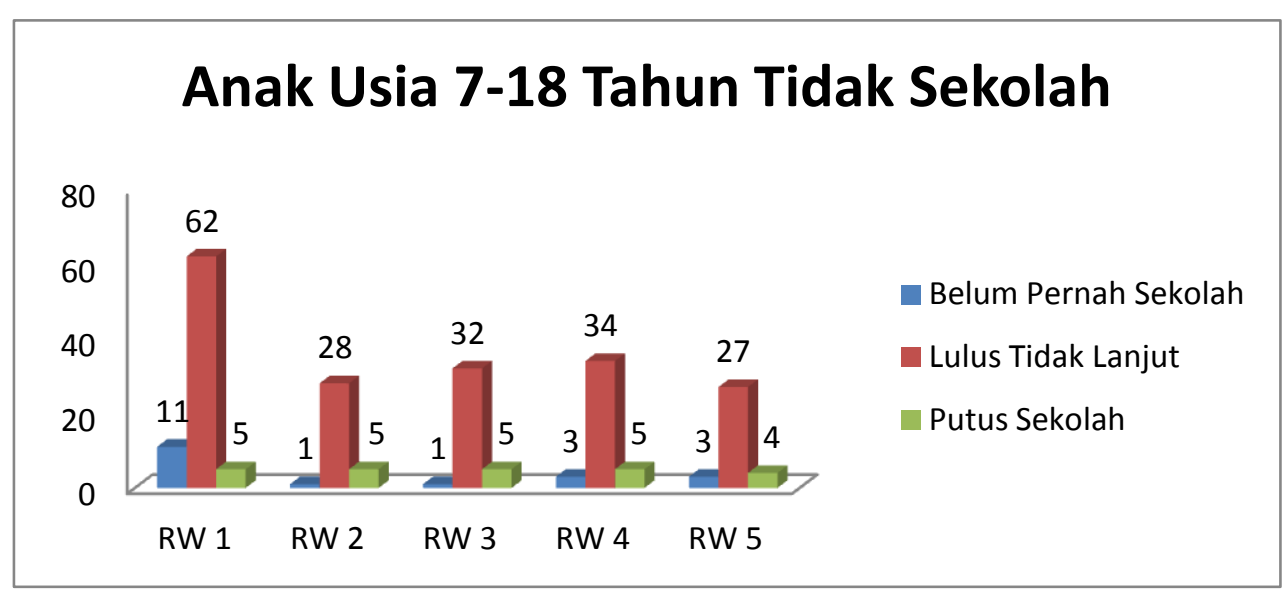

Gb. 2. Diagram Anak Usia Sekolah di Desa Parereja

Program RPJMD Kabupaten Brebes ditujukan untuk mengurangi tingkat kemiskinandan meningkatkan peringkat Indeks Pembangunan Manusia (IPM). IPM merupakan indikator komposit tunggal yang walaupun tidak dapat mengukur semua dimensi dari pembangunan manusia, tetapi mengukur tiga dimensi pokok pembangunan manusia yang dinilai mampu mencerminkan kemampuan dasar (basic capabilities) penduduk. Ketiga kemampuan dasar itu adalah umur panjang dan sehat, berpengetahuan dan berketerampilan, serta akses terhadap sumber daya yang dibutuhkan untuk mencapai standar hidup layak (Setiawan, 2013). Dalam RPJMD Kabupaten Brebes, dirumuskan beberapa masalah kebijakan serta isu strategis Kabupaten Brebes. Isu strategis yaitu: pendidikan dan kesehatan menduduki isu strategis pertama dan kedua. Pendidikan merupakan sarana untuk meningkatkan kualitas sumberdaya manusia yang menjadi objek dan subjek pembangunan. Kesehatan, faktor kesehatan masyarakat merupakan faktor penting dalam pelaksanaan program pembangunan. Kualitas kesehatan yang baik akan memberikansumberdayamanusiayangsiapu ntuk melaksanakan pembangunan suatu negara. Penanganan kesehatan yang sinergisdengan faktor lingkungan menjadi penting mengingat bahwa pada pelaksanaannya upaya penanganan kesehatan di samping upaya kuratif berupa pengobatan setelah masyarakat terkena penyakit, ada juga upaya promotif dan preventif sebagai upaya peningkatan kualitas dan menjaga kesehatan masyarakat agar tidak mudah terjangkiti penyakit. Konsep penanganan kesehatan secara promotif dan preventif mendorong adanya pemahaman bahwa faktor kesehatan lingkunganmerupakan aspek penting dalam menjaga kesehatan masyarakat. Upaya 
preventif juga promotif dalam konsep penanganan kesehatan adalah melalui kegiatan Posyandu yang menitikberatkankepada penanganan kesehatan balita (RPJMD Kabupaten Brebes 2012-2017). Hasil penelitian menunjukkan bahwa ada hubungan positif yang signifikan antara status kesehatan denganpengetahuan tentang kesehatan lingkungan, perilaku hidup sehat, dan tingkat pendidikan.Hubungan dari ketiga variabel bersama-sama dapat berkontribusi sebesar $55 \%$ terhadap status kesehatan seseorang (Sulistyowati, 2013).
Isu strategis dalam RPJMD Kabupaten Brebes merumuskan permasalahan yang ada dan alternative faktor-faktor penentu keberhasilannya sebagai acuan penentuan program. Adapun isu-isu strategis tersebut khususnya pada isu pendidikan dan kesehatan antara lain di sajikan berturut-turut pada Tabel 3 dan Tabel 4 berikut.

Tabel 3. Isu-isu Strategis Bidang Pendidikan sebagai Acuan Program Pembangunan Kabupaten Brebes

Permasalahan FOKUS KESEJAHTERAAN MASYARAKAT

(1) Masih rendahnya tingkat partisipasi sekolah

(2) Ketersediaan sarana prasarana sekolah yang belum menjangkau seluruh wilayah

(3) Tingginya angka kemiskinan FOKUS LAYANAN UMUM

Masih rendahnya partisipasi sekolah pada jenjang pendidikan menengah
(1) Fasilitasi dan bantuan bagi siswa miskin untuk melanjutkan pendidikan

(2) Peningkatan kuantitas dan kualitas sarana dan prasarana pendidikan
Faktor-faktor Penentu Keberhasilan (Acuan Program)

(1) Optimalisasi bantuan beasiswa pada semua jenjang pendidikan;

(2) Optimalisasi dana BOS di jenjang pendidikan dasar

Sumber: RPJMD Brebes 2017-2022

Data ini menunjukkan bahwa permasalahan pendidikan dan kemiskinan pendidikan dan tinggginya angka maka focus layanan umumnya adalah kemiskinan menjadi isu prioritas dalam fasilitasi bantuan bagi siswa yang tidak pembangunan Kabupaten Brebes. Pada mampu. table dapat dilihat dengan adanya 
Tabel 4. Isu-isu Strategis Bidang Kesehatan sebagai Acuan Program Pembangunan Kabupaten Brebes

\begin{tabular}{|c|c|}
\hline Permasalahan & $\begin{array}{c}\text { Faktor-faktor Penentu Keberhasilan } \\
\text { (Acuan Program) }\end{array}$ \\
\hline \multicolumn{2}{|c|}{ FOKUS KESEJAHTERAAN MASYARAKAT } \\
\hline $\begin{array}{l}\text { (1) Rendahnya pemahaman Ibu Hamil akan } \\
\text { keselamatan dan kesehatan bayi } \\
\text { (2) Tingginya angka kemiskinan } \\
\text { (3) Jumlah tenaga kebidanan yang belum } \\
\text { ideal dengan jumlah penduduk }\end{array}$ & $\begin{array}{l}\text { (1) Edukasi terhadap ibu hamil } \\
\text { (2) Peningkatan kuantitas dan kualitas } \\
\text { serta akses terhadap sarana dan } \\
\text { prasarana kesehatan }\end{array}$ \\
\hline \multicolumn{2}{|c|}{ FOKUS LAYANAN UMUM } \\
\hline $\begin{array}{l}\text { Kesadaran ibu hamil untuk memeriksa kesehatan } \\
\text { kehamilannya perlu ditingkatkan }\end{array}$ & $\begin{array}{l}\text { Sosialisasi pentingnya kesehatan kehamilan } \\
\text { khususnya bagi Ibu Hamil dari keluarga } \\
\text { miskin }\end{array}$ \\
\hline $\begin{array}{l}\text { Kesadaran akan pentingnya pemeriksaan } \\
\text { kesehatan bayi secara berkala perlu ditingkatkan } \\
\text { lagi }\end{array}$ & $\begin{array}{l}\text { Sosialisasi akan pentingnya pemeriksaan } \\
\text { kesehatan bayi secara rutin di pusat-pusat } \\
\text { pelayanan kesehatan }\end{array}$ \\
\hline $\begin{array}{l}\text { Kesadaran keluarga untuk memeriksa secara } \\
\text { rutin anak balitanya di pusat- pusat layanan } \\
\text { kesehatan masih rendah }\end{array}$ & $\begin{array}{l}\text { Sosialisasi akan pentingnya pemeriksaan } \\
\text { kesehatan balita secara rutin di pusat- pusat } \\
\text { pelayanan kesehatan }\end{array}$ \\
\hline $\begin{array}{l}\text { Belum seluruh sekolah memiliki Guru UKS serta } \\
\text { dokter kecil serta belum optimalnya peranan } \\
\text { tenaga kesehatan mengintervensi sekolah dasar }\end{array}$ & $\begin{array}{l}\text { Sosialisasi dan } \\
\text { serta dokter kecil }\end{array}$ \\
\hline
\end{tabular}

Permasalahan Kabupaten Brebes menggambarkan permasalahan di tingkat Kecamatan dan desa wilayah Kabupaten Brebes. Banyak program telah dilaksanakan, namun belum memberikan hasil yang signifikan. Hal ini dimungkinkan karena keberadaan data yang kurang akurat (Abidin, 2016). Kabupaten Brebes bersama Unicef dan UNNES telah mengaplikasikan SIPBM sebuah sistem informasi pembangunan berbasis masyarakat, yang salah satunya desa Parereja sebagai desa pilot project. Dengan sistem tersebut telah didapatkan data by name by address. Selanjutnya data tersebut dijadikan acuan dalam penyusunan program desa. Berdasarkan pada berbagai permasalahan yang ada, permasalahanpermasalahan yang menjadi prioritas telah disepakati bersama Kabupaten Brebes dan perguruan tinggi mitra (AKBID YPBHK) untuk ditangani melalui Program Kemitraan Wilayah (PKW), bidang pendidikan, yaitu: (1) Belum tersedianya data berbasis masyarakat di desa Cigadung, (2) Cukup banyak anak usia dini belum terlayani di PAUD, (3) Masih terdapat anak usia sekolah pendidikan dasar tidak sekolah (belum pernah sekolah, putus sekolah, lulus tidak lanjut), (4) Cukup tinggi anak tamat SD dan SMP tidak lanjut ke jenjang yang lebih tinggi, (5) Cukup

\section{3 | Journal of Dedicators Community UNISNU Jepara}


tinggi anak usia sekolah pendidikan dasar tidak skolah dengan alas an "tidak memiliki biaya", (6) Cukup tinggi anak usia sekolah pendidikan dasar tidak sekolah dengan alasan "tidak mau sekolah. Bidang kesehatan, yaitu: (1) Tingginya anak stunting dan angka kematian Ibu, (2) Kesadaran gizi Ibu hamil dan anak balita rendah, (3) Minimnya pelayanan kesehatan bagi anak di sekolah yang ada, (4) Status penduduk di kedua desa masih "miskin", dan (5) Kesadaran pentingnya lingkungan sehat masyarakat masih rendah

Permasalahan-permasalahan prioritas ditujukan untuk mendukung kearah pencapaian (1) meningkatkan angka partisipasi sekolah anak usia sekolah di desa Parreja dan Cigadung pada bidang pendidikan, dan (2) meningkatkan lama harapan hidup masyarakat desa Parireja dan Cigadung pada bidang kesehatan. Oleh karena itu, agar solusi dari permasalahanpermasalahan tersebut mampu mendukung terhadap tujuan peningkatan bidang pendidikan dan kesehatan tersebut yang keduanya saling terkait, maka telah dirancang program-program sebagai solusi secara sistematis, dirancang untuk 3 tahun. Adapun solusi yang telah dilaksanakan pada tahun pertama sesuai kesepakatan dengan mitra adalah : (1) . Menyelenggarakan SIPBM (Sistem Informasi Pendidikan Berbasis
Masyarakat) di desa Cigadung; (2) Pembentukan dan Penguatan POSPAUD; (3) Pembentukan dan penguatan SDM PKBM di Desa Parereja; (4) Meningkatkan layanan kesehatan bagi siswa di sekolah melalui UKS dan dokter kecil

\section{METODOLOGI}

PEMECAHAN

\section{MASALAH}

Mengacu pada solusi atas permasalahan prioritas wilayah, langkahlangkah atau tahapan yang telah ditempuh dalam pelaksanaan solusi yang ditawarkan dijelaskan sebagaimana berikut. Permasalahan belum tersedianya data berbasis masyarakat di desa Cigadung, diatasi dengan program Menyelenggarakan SIPBM di Desa Cigadung dengan langkahlangkah: Sosialisasi SIPBM bagi masyarakat desa Cigadung; Pelatihan Pendataan SIPBM bagi masyarakat terpilih desa Cigadung; Pendataan; Entry data, Clearing data; dan penyusunan Buku Saku SIPBM desa Cigadung Kecamatan Banjarharjo, Kabupaten Brebes. Metode yang diterapkan: Ceramah, Tanya jawab, demonstrasi, simulasi, try-out, praktik lapangan, pendampingan. Dengan tersedianya Buku Saku SIPBM desa Cigadung, maka buku tersebut menjadi acuan dalam menyusun program-program desa tahun berikutnya. 
Permasalahan cukup banyak anak usia dini belum terlayani di PAUD. Untuk mengatasi permasalahan tersebut, dilakukan program pembentukan dan penguatan POSPAUD di desa Parireja. Kegiatan diawali dengan pelatihan kader POSPAUD di desa Parereja, penyediaan APE POSPAUD, dan implementasi POSPAUD di desa Parereja dan Pendampingan di desa Parereja. Pendekatan yang diterapkan: Learning by doing, demontrasi, simulasi, praktik dan pendampingan Learning by doing. Beberapa mahasiswa terlibat dalam pelatihan dan mahasiswa $\mathrm{KKN}$ terlibat dalam pendampingan implementasi POSPAUD di desa Parereja.

Permasalahan masih terdapat anak usia sekolah pendidikan dasar tidak sekolah (belum pernah sekolah, putus sekolah, lulus tidak lanjut), diatasi dengan penyelenggaraan dan penguatan layanan PKBM di Parereja dengan pendekatan diskusi terfokus (FGD) dan kerja kelompok. Implementasi PKBM desa Parereja bekerjasama dengan FMPP (Forum Masyarakat Peduli Pendidikan) Desa Parereja. FMPP desa Parereja bertugas dalam mengelola dan menyelenggarakan pengembalian anak ke sekolah yang dikenal dengan Gerakan Kembali Bersekolah (GKB), sedangkan anak usia tidak sekolah yang tidak memungkinkan dikembalikan ke sekolah, atau tidak mau sekolah menjadi tugas PKBM. Keberadaan PKBM desa Parereja sekaligus sebagai program untuk mengatasi permasalahan status penduduk desa Parererja yang masih miskin. Kegaiatan yang sudah dilaksanakan untuk mengatasi masalah ini dengan pendidikan keterampilan produktif bagi kelompok wanita. Kegiatan ini dilaksanakan dengan metode learning by doing. Pelaksanaan GKB oleh FMPP dilakukan dengan metode koordinasi dengan Dinas Pendidikan Kab. UPTD, dan Sekolah. Penyelenggaraan GKB dengan dana desa sebagai implementasi peraturan Bupati kabupaten Brebes yang telah diberlakukan.

Permasalahan yang terakhir adalah minimnya pelayanan kesehatan bagi anak di sekolah yang ada. Untuk mengatasi permasalahan ini telah dilakukan program untuk memberikan layanan kesehatan bagi siswa di sekolah, dengan menyelenggarakan pelatihan UKS bagi guru SD di Desa Parireja dan Cigadung, dilanjutkan pelatihan Dokter Kecil bagi siswa SDN di desa Parereja dan Cigadung, dilanjutkan implementasi dan pendampingan UKS di Sekolah dan Dokter Kecil di SDN di Parereja dan Cigadung. Kegiatan dilaksanakan dengan pendekatan atau metode yang diterapkan: ceramah, tanya jawab, simulasi, serta praktik. 
Kegiatan yang sudah ditawarkan disusunnya struktur organisasi sebagaimana untuk mengatasi permasalahan telah disajikan pada Gambar 3 berikut. disepakati bersama tim pelaksana dan Baperlitbangda kabupaten Brebes. Pengorganisasian kegiatan dilakukan untuk mempermudah koordinasi dengan

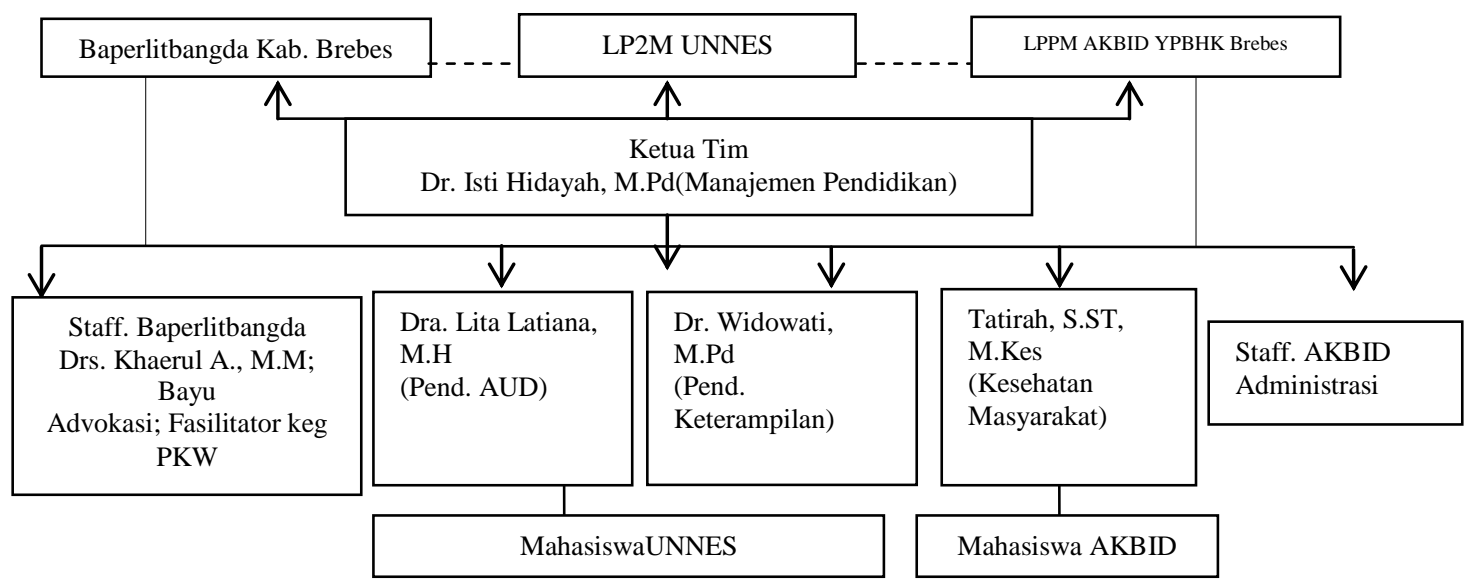

Gb. 3. Struktur Organisasi Tim Pelaksana PKW

\section{HASIL}

Kegiatan pengabdian masyarakat ini dilaksanakan dengan beberapa program yang diterapkan pada bagian masyarakat desa Parereja dan Cigadung. Hasil dari pelaksanaan program tersebut adalah:

1. Buku Saku SIPBM Desa Cigadung, Kecamatan Banjarharjo, Kabupaten Brebes;

2. Terbentuknya POSPAUD Ceria di Desa Parereja dan pendampingan serta advokasi untuk keberlanjutannya;

3. Terbentuknya Pusat Kegiatan Belajar Masyarakat dan Forum Masyarakat
Peduli Pendidikan untuk mengawal kegiatan PKBM;

4. Penguatan implementasi UKS dan Dokter kecil di SD untuk memberikan pelayanan kesehatan.

\section{PEMBAHASAN}

\section{Penyelenggaraan SIPBM di Desa Cigadung}

Penyelenggaraan

pendataan berbasis masyarakat yang selanjutnya disebut SIPBM (Sistem Informasi Pembangunan Berbasis Masyarakat) di desa Cigadung telah didahului dengan kegiatan rapat koordinasi Tim pelaksana 
program, kepala desa Parereja yang telah melaksanakan SIPBM tahun sebelumnya, kepala desa Cigadung sebagai desa sasaran, wakil dari Baperlitbangda kabupaten Brebes, tokoh masyarakat terpilih sebagai fasilitator kegiatan PKW di lokasi sasaran. Selanjutnya penentuan khalayak sasaran, yaitu 85 orang masyarakat sasaran sosialisasi program yang terdiri atas calon pendata 18 orang, Koramil Kecamatan 1 orang, perangkat desa 11 orang, BPD (Badan Permusyawaratan Desa) 1 orang, LPM (Lembaga Pemberdayaan Masyarakat) 1 orang, RT RW 35 orang, tokoh masyarakat dan tokoh agama 6 orang, TOPENDIK 3 orang, fasilitator 2 orang, narasumber 1 orang, PKK 1 orang, Muspika 3 orang. Kegiatan sosialisasi dilaksanakan di Balai Desa Cigadung, selain undangan hadir kepala desa Cigadung beserta perangkatnya, Baperlitbangda kabupaten brebes sekaligus sebagai narasumber.

Calon pendata SIPBM sebanyak 18 orang ditentukan oleh kepala desa untuk mengikuti pelatihan pendataan SIPBM. Penyiapan logistik pelatihan pendataan SIPBM dan pelaksanaan pendataan yang berupa: IK (Instrumen Keluarga) 3 halaman digandakan sebanyak jumlah peserta dikalikan 4 rangkap $(18 \times 4=72)$ ukuran A3/jumbo, sampul IK digandakan sebanyak jumlah peserta saja (18 buah), panduan IK sebanyak jumlah peserta + Tim Pelatih 2 orang (20 buah), IK cetak baliho dengan ukuran: IK Halaman 1 ukuran $120 \mathrm{~cm} \times 120 \mathrm{~cm}$ (Portrait), IK halaman 2 ukuran $120 \mathrm{~cm} \times 120 \mathrm{~cm}$ (Portrait), IK Halaman 3 ukuran $200 \mathrm{~cm}$ X $150 \mathrm{~cm}$ (Landscape), masing-masing 1 buah (tanpa sampul), kertas plano untuk membuat peta lokasi sasaran pendataan IK menggunakan IK yang telah digunakan oleh Baperlitbangda Kabupaten Brebes. IK ini adalah instrumen yang dikembangkan oleh UNICEF. Sedangkan logistik untuk pendataan terdiri atas: pencetakan IK sebanyak $1850 \mathrm{KK}$ yang ada di $30 \mathrm{RT}$, stiker pendataan SIPBM, identitas pendata, ATK (Pensil, Ballpoint, penghapus, pemes/serutan, Tinta dan bantalan, tas). Pelatihan pendataan dilaksanakan selama 2 hari dengan pendekatan dan metode ceramah, tanya jawab, demonstrasi, simulasi, try-out, praktik lapangan, pendampingan.

Pendataan dan Clearing Data, Pendataan dilaksanakan selama 2 minggu (20 hari) oleh pendata dengan pendampingan. Clearing data dilakukan oleh pendamping. Clearing data dilakukan bersamaan dengan pendataan, dimulai 2 hari setelah pendataan dilakukan. Entry data dilakukan di Kantor Bapperlitbangda, didahului dengan pelatihan/penyegaran entry data. Entry data dilakukan dengan 
program yang sudah digunakan oleh Bapperlitbangda kabupaten Brebes, dikembangkan oleh UNICEF. Hasil analisis data pendataan SIPBM desa Cigadung, selanjutnya disusun dalam sebuah buku "Buku Saku SIPBM Desa Cigadung, Kecamatan Banjarharjo, Kabupaten Brebes". Semua informasi atau data hasil hasil analisis SIPBM tertuang dalam Buku Saku tersebut, buku tersebut diserahkan kepada Baperlitbangda Kabupaten Brebes dan Kepada Desa Cigadung, yang selanjutnya dapat digunakan sebagai acuan penyusunan program desa Cigadung. Konstribusi pemerintah daerah dalam kegiatan ini adalah melakukan advokasi pentingnya SIPBM, menyediakan fasilitator kabupaten, menyediakan tempat dan memfasilitasi pelaksanaan entry data, melakukan monitoring, sebagai penjamin mutu keberlanjutan program.

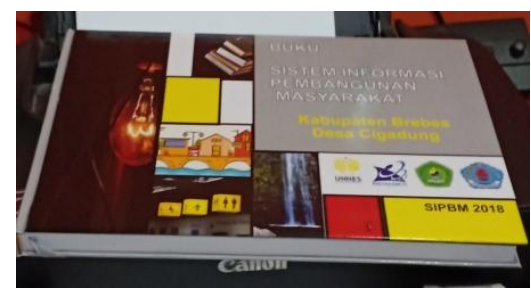

Gb. 4 Buku Saku SIPBM Desa Cigadung

\section{Pembentukan dan Penguatan POSPAUD di Desa Parireja}

POSPAUD dibentuk dari POSYANDU yang ada di desa Parereja. Penguatan POSPAUD yang dilakukan pada program tahun 2018 ini meliputi pelatihan kader POSPAUD di desa Parereja, bantuan APE, dan implementasi POSPAUD dengan pendampingan. Pelatihan kader POSPAUD diikuti oleh kader POSYANDU Asoka 1, 2, 3, dan 4 yang berada di desa Parereja sebanyak 25 orang. Instruktur pada pelatihan kader POSPAUD adalah pakar PGPAUD dan Ketua Himpaudi Kecamatan Banjarharjo; pakar kebidanan dari Akbid YBHK Brebes, Bidan Desa, dan Ibu Kepala Desa mewakili perangkat desa. POSPAUD merupakan integrasi kegiatan POSYANDU dan PAUD, sehingga program atau kegiatan POSYANDU untuk memberikan edukasi dan pelayanan kesehatan ibu hamil, bayi, dan balita, sekaligus program untuk kegiatan layanan anak usia dini.

Telah disepakati bersama dari desa dan kader, untuk POSPAUD yang dibentuk adalah POSPAUD CERIA dan dilaunching pada hari Minggu tanggal 29 April 2018. Bantuan APE antara lain: Mobil-mobilan warna, Balok Bangun Kecil, Kapal barang, Menara Bentuk 5, Balok Angka. Pendampingan implementasi juga dilakukan oleh mahasiswa KKN. Konstribusi pemerintah daerah dalam kegiatan ini adalah melakukan advokasi 
kepada FMPP (Forum Masyarakat Peduli Pendidikan) melakukan koordinasi dengan Dinas Pendidikan Kabupaten, UPTD, SKPD terkait, sekolah untuk melakukan evaluasi dan monitoring sebagai penjaminan mutu keberlanjutan program.

\section{Pembentukan PKBM (Pusat Kegiatan}

\section{Belajar Masyarakat) Desa Parereja}

Pembentukan dan penguatan PKBM

Desa Parereja dimaksudkan untuk memberikan akses pendidikan bagi masyarakat desa Parereja pada umumnya. Penguatan yang telah dilakukan adalah kegiatan diskusi terfokus (FGD), khususnya mendiskusikan tentang kegiatan- kegiatan yang bisa diprogramkan untuk mendukung anak usia sekolah tidak sekolah dan tidak mungkin kembali ke sekolah, juga memfasilitasi warga masyarakat secara umum untuk dapat berkesempatan akses pendidikan. Diskusi terfokus diikuti juga oleh pengurus FMPP bertanggungjawab atas terselenggaranya GKB (Gerakan Kembali Bersekolah).

Program GKB merupakan salah satu tindak lanjut implementasi SIPBM UNICEF di desa Parereja. Kedua wadah organisasi desa ini saling bersinergi dalam mengatasi masalah partisipasi pendidikan bagi masyarakat desa Parereja. FMPP menangani anak usia sekolah yang tidak sekolah, sedangkan PKBM menangani anak usia sekolah tidak sekolah yang tidak mungkin kembali ke sekolah, juga memfasilitasi warga masyarakat secara umum untuk dapat berkesempatan akses pendidikan.

FMPP sebagai pelaksana program GKB tahun ini telah mengembalikan anak usia sekolah tidak sekolah dengan dana desa. Sebagai tindak lanjut dari kegiatan penguatan PKBM, melalui PKW telah dilakukan pelatihan keterampilan produktif bagi kelompok perempuan guna menunjang ekonomi keluarga. Keterampilan yang diberikan dengan pendekatan learning by doing, membuat bross, pita dari bahan pita, barang rumah tangga dari bahan koran bekas, serta membuat mascraft tali pada botol bekas. Konstribusi pemerintah daerah dalam pelaksanaan kegiatan ini adalah melakukan advokasi ke pemerintah desa, dan tokoh masyarakat, melakukan monitoring dan evaluasi, sebagai penjaminan mutu keberlanjutan program.

\section{Pelayanan Kesehatan bagi Siswa di Desa Cigadung dan Parereja}

Pelayanan kesehatan bagi siswa di sekolah dalam program kemitraan wilayah ini dilakukan melalui penguatan implementasi UKS dan dokter kecil. Penguatan dilakukan dengan Training of Trainer (TOT) bagi guru wakil sekolah 
yang ada di desa Parereja dan Desa Cigadung. Terdapat 3 SD di desa Parereja dan 3 SD di Desa Cigadung, berturut-turut SDN Parereja 1, SDN Parereja 2, SD N Parereja 3, SD N Cigadung 1, SD N Cigadung 2, dan SD N Cigadung 3. Tiap SD diwakili oleh 2 orang guru. Materi yang diberikan mencakup teori dan praktik yang dikemas dalam panduan. ToT dilaksanakan selama 1 hari. Sedangkan hari berikutnya dilanjutkan dengan pelatihan dokter kecil diikuti oleh 24 orang anak, tiap sekolah mengirim 4 orang anak disertai guru pendamping.

Kegiatan dilaksanakan dengan ceramah dan banyak praktik atau simulasi. Narasumber kegiatan adalah pelaksana dari AKBID YPBHK Brebes dan tenaga kesehatan dari Puskesmas Banjarharjo. Implementasi di sekolah, sebagai SD model dipilih SD N 1 Parereja dan SD N 1 Cigadung, yaitu sekolah yang memiliki ruang UKS sekaligus sebagai sekolah model. Bantuan peralatan kesehatan sesuai standar pelaksanaan UKS berupa 1 set dengan 13 item alat kesehatan telah diberikan.

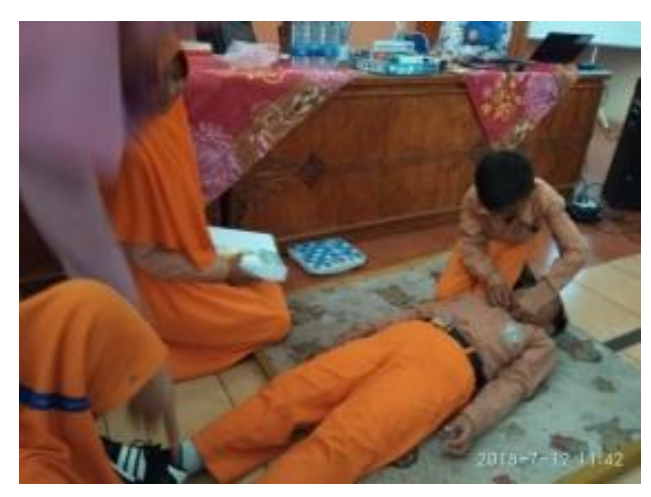

Gb.5. Pelatihan Dokter Kecil bagi Siswa

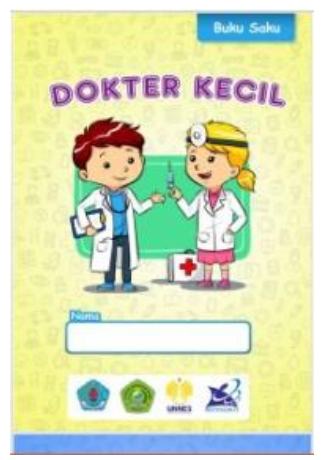

Gb. 6. Cover Buku Saku

Kontribusi pemerintah daerah dalam kegiatan ini adalah melakukan koordinasi dengan Dinas Pendidikan Kabupaten Brebes dan Puskesmas Kecamatan Banjarharjo terkait, untuk menjamin keberlanjutan program.

\section{SIMPULAN}

Kesimpulan dari pelaksanaan Program kemitraan Wilayah ini adalah: (1) Replikasi SIPBM Desa Cigadung dapat terlaksana dengan baik, telah menghasilkan Buku Saku SIPBM yang siap digunakan untuk acuan penyusunan program desa Cigadung tahun selanjutnya, khususnya program pendidikan dan kesehatan. Dengan mudah desa Cigadung dalam 
memfasilitasi akses pendidikan bagi warganya, mementukan anak usia sekolah tidak sekolah yang akan dikembalikan ke sekolah, bantuan jamban keluarga dan lainnya, karena Buku Saku SIPBM dilengkapi data by name by address. (2) Terbentuknya PKBM dan peningkatan mutu SDM pengurusnya desa Parereja bersama FMPP siap berperanserta memfasilitasi masyarakat secara umum dalam akses pendidikan. (3) Kelompok perempuan desa Parereja mampu menghasilkan produk keterampilan berupa bross dan pita, macrame wadah bekas, maupun karya dari limbah Koran yang layak jual. (4) Pembentukan POSPAUD CERIA memfasilitasi anak usia PAUD mendapatkan layanan pendidikan. (5) Pelatihan UKS dan Dokter Kecil meningkatkan pengetahuan dan keterampilan penggunaan peralatan kesehatan bagi guru dan siswa untuk memberikan layanan kesehatan kepada siswa di sekolah.

\section{SARAN}

Untuk menjamin keberlanjutan kegiatan-kegiatan program kemitraan wilayah disarankan, agar dilakukan koordinasi terprogram antara pemerintah desa dan pemerintah daerah (Baperlitbangda) kabupaten Brebes, atau SKPD terkait dalam merancang, melaksanakan, dan melakukan evaluasi, serta tindak lanjut, mengingat program desa merupakan program untuk mengatasi permasalahan pemerintah daerah. Pemerintah desa juga tetap melakukan koordinasi dengan perguruan tinggi mitra, khususnya perguruan tinggi setempat.

\section{UCAPAN TERIMAKASIH}

Ucapan terimakasih disampaikan kepada Direktur Ristekdikti yang telah mendanai kegiatan Program Kemitraan Wilayah, Kepada Kepala Baperlitbangda Kabupaten Brebes, Kepala Desa Parereja, Kepala Desa Cigadung, OPD terkait, pendamping desa, Kepala LP2M UNNES, Kepala LPPM AKBID YPBHK Brebes, Kepala Pusat KKN UNNES yang telah memfasilitasi terselenggaranya kegiatan PKW ini, baik berupa pendampingan dana maupun dukungan bentuk lain.

\section{DAFTAR PUSTAKA}

Abidin, Khaerul. 2016. Satu Data untuk Semua. Info TKPK. Edisi kelima Tahun 2016. Halaman 13-14

Badan Pusat Statistik Kabupaten Brebes. 2016. Kabupaten Brebes dalam Angka 2016. Brebes: BPS Kabupaten Brebes.

Baperlitbangda. 2016. Data Kemiskinan dan IPM Kabupaten Brebes 20102016.(Materi paparan Kabid Pemsosbud, Baperlitbangda Kabupaten Brebes) 
Rahayu, W. W. (2014). Empathy Grown Through KKN PPM UGM Towards Unity and Coalescence Of Pamulihan Community. Jurnal Pengabdian Sriwijaya, 2(2), 167-182.

Setiawan, M. B., \& Hakim, A. (2013). Indeks pembangunan manusia Indonesia. Jurnal Economia, 9(1), 18-26.

Pradono, J., \& Sulistyowati, N. (2014). (Correlation between Education Level, Knowledge of Environmental Health, Healthy Behavior with Health Status) Correlation Study on People Aged 1024 in Jakarta Pusat. Buletin Penelitian Sistem Kesehatan, 17(1 Jan). doi:10.22435/bpsk.v17i1 Jan.3579

2016. Basis Data Terpadu (BDT) Tahun 2015 Kabupaten Brebes. Info TPK. Edisi kelima Tahun 2016, halaman 29-30.

2012. RPJMD Kabupaten Brebes Tahun 2012-2017. Baperlitbangda Kabupaten Brebes

2017. RPJMD Kabupaten Brebes Tahun 2017-2022 (Draft).

Baperlitbangda Kabupaten Brebes 